\title{
Characterization and selection of
} "Maracujá-do-mato" (Passiflora cincinnata mast) morphoagronomic descriptors

\author{
Jéssica Alves Dutra ${ }^{1}$, Antonio Carlos de Oliveira ${ }^{2}$, \\ Antonio Carlos Mota Porto ${ }^{3}$, Jéssika Layanne Moreira Mathias ${ }^{4}$ \\ Abstract - The present study consists of the in situ characterization and selection of minimal \\ morphoagronomic descriptors in Passiflora cincinnata genotypes. Forty-one quantitative \\ morphoagronomic descriptors were used, divided in "Plant and Leaf", "Floral" and "Fruit". Principal \\ component analysis were used to eliminate descriptors that were less important in the study of \\ multivariate dissimilarity among genotypes. The formation of groups was carried out using Ward's \\ hierarchical grouping method. The importance of the characters was estimated through the participation \\ of the components by Singh's method (1981) in order to verify the similarity between lower participation \\ variables in the components. For the set of descriptors "Plant and Leaf" the characteristics that presented \\ the greatest relative contributions were: maximum leaf width $76.1 \%$ and leaf blade length $17.2 \%$. For \\ the set of descriptors "Floral" the characteristics that presented the greatest relative contributions were: \\ pedicel length $42.1 \%$, corona tip diameter $32.6 \%$ and petal length $11.8 \%$. For the set of descriptors \\ "Fruit" the characteristic that presented the greatest relative contribution was: number of seeds per \\ fruit $89.2 \%$. From the results obtained, we can infer that from the 41 descriptors, only 15 were relevant \\ for the evaluation of the genetic diversity among the individuals of the population. These descriptors \\ were: titratable acidity, bract length, leaf blade length, petal length, sepal length, pedicel length, corona \\ filament ring length, corona tip diameter, fruit longitudinal diameter, sepal width, maximum leaf width, \\ number of fruits, number of seeds per fruit, bark weight and fruit mass. \\ Index terms: Principal components, hierarchical grouping, Singh's method.

\section{Caracterização e seleção de descritores morfoagronômicos de "Maracujá-do-mato" (Passiflora cincinnata mast)}

\section{Corresponding author: jessicadutra_bio@hotmail.com}

Received: April 01, 2019 Accepted: July 24, 2019

Copyright: All the contents of this journal, except where otherwise noted, is licensed under a Creative Commons Attribution License.

\section{(cc) $\mathbf{E}$ Y}

Resumo - O presente estudo consiste na caracterização e na seleção de descritores morfoagronômicos mínimos em genótipos de Passiflora cincinnata in situ. Foram utilizados 41 descritores morfoagronômicos quantitativos, divididos em "Planta e Folha", "Floral" e "Fruto". Utilizou-se a análise de componentes principais com o objetivo de eliminar descritores que tivessem menor importância no estudo de dissimilaridade multivariada entre genótipos. Foi realizada a formação de grupos por meio do método de agrupamento hierárquico de Ward. Foi estimada a importância dos caracteres por meio da participação dos componentes pelo método de Singh (1981), com o intuito de verificar a similaridade entre variáveis de menor participação dos componentes. Para o grupo de descritores "Planta e Folha", as características que apresentaram as maiores contribuições relativas foram: largura máxima da folha (76,1\%) e comprimento da lâmina foliar (17,2\%). Para o grupo de descritores "Floral", as características que apresentaram as maiores contribuições relativas foram: comprimento do pedicelo $(42,1 \%)$, diâmetro da ponta da corona $(32,6 \%)$ e comprimento da pétala $(11,8 \%)$. Para o grupo de descritores "Fruto", a característica que apresentou a maior contribuição relativa foi: número de sementes por fruto $(89,2 \%)$. A partir dos resultados obtidos, pode-se inferir que, dos 41 descritores, apenas 15 se mostraram relevantes para a avaliação da diversidade genética entre os indivíduos da população. Estes descritores foram: acidez titulável, comprimento da bráctea, comprimento da lâmina foliar, comprimento da pétala, comprimento da sépala, comprimento do pedicelo, comprimento dos anéis dos filamentos corona, diâmetro da ponta da corona, diâmetro longitudinal do fruto, largura da sépala, largura máxima da folha, número de frutos, número de sementes por fruto, peso da casca e massa do fruto.

Termos para indexação: Componentes principais, agrupamento hierárquico, método de Singh. 


\section{Introduction}

There is a great variety of fruit plants that occur in the Caatinga biome and/or adapted to the dry conditions, of exotic flavors, which attend to the current trends of natural products consumption, that reinforces the initiatives of collection, characterization and cultivation in commercial scale of these fruit trees (Kiill et al., 2008). There are only about 70 effectively edible Passiflora species (Cunha et al., 2002). Among them, the wild species Passiflora cincinnata Mast, popularly known in Brazil as "Maracujádo-Mato" or "Maracujá-de-Boi" (Nunes \& Queiroz, 2006) stands out. Among P. cincinnata populations, there are vigorous and very diverse plants, showing variation in flower color, fruit size, juice color and taste (Oliveira \& Ruggiero, 2005).

This wild Passiflora species is used in large scale in fruit extractivism, which generates seasonal employment and income in the countryside (Junior et al., 2010; Pereira et al., 2012), and it is characterized by its resistance to long periods of drought (Pereira et al., 2012). This characteristic, allied to the general rusticity in field conditions, could be incorporated to commercial passion fruit (Junqueira et al., 2005).

The main prerequisite for initiating a genetic breeding program for a particular plant species is the genetic variability characterization (Faleiro et al., 2006a; Lopes \& Carvalho, 2008). This can be done by using genetically inherited descriptors: physiological, biochemical, molecular or morphological (Machado et al., 2006).

Morphoagronomic descriptors are important for conservation programs, germplasm use, genetic improvement of plants, registration and protection of cultivars, besides being a valuable means of characterizing plants and Passiflora species, and quantifying the existing variability (Jesus et al. al., 2017). The genetic variability characterization and quantification of $P$. cincinnata using morphoagronomic descriptors do not count on in situ studies.

The characterization of Passiflora cincinnata using morphoagronomic descriptors has not been accompanied by a list of minimum descriptors. The importance of identifying them exist due to the demand to discern which ones are necessary and which can be discarded (Beale et al., 1967). Discarding variables that do not provide extra information is critical, because it will reduce time and costs in future reviews, without considerable loss of information (Barbosa et al., 2005).

The evaluation of genotypes of this passion fruit species through the use of morphoagronomic descriptors, aiming at identifying, among the descriptors, redundant variables do not count on in situ studies.

The present work deals with the in situ identification of minimal morphoagronomic descriptors in Passiflora cincinnata genotypes.

\section{Material and methods}

Plant genetic material. A total of 53 individuals of passion fruit ( $P$. cincinnata) were sampled, under nonirrigated in situ conditions, on a $50 \mathrm{~km}$ road adjacent to the municipalities of Vitória da Conquista and Belo Campo, both located in the state of Bahia, Brazil, at an altitude from 840 to $892 \mathrm{~m}$ above sea level, with latitude between $14^{\circ} 95$ ' $38.7^{\prime} \mathrm{S}$ and $15^{\circ} 01^{\prime}$ ' 59.6 'S , longitude between $40^{\circ} 97^{\prime} 97.8^{\prime} \mathrm{W}$ and $41^{\circ} 17^{\prime} 21.1^{\prime} \mathrm{W}$, Cwa climate (mesothermal with dry winter, commonly named tropical de altitude) with annual average rainfall of 712 mm (CLIMATE-DATA.ORG, 2018).

The area where the collections took place was determined through prospective trips and also through contacts with residents of the region who work with "Maracujá-do-Mato" extraction and whose commercialization takes place in the Central de Abastecimento de Vitória da Conquista (CEASA).

In the area where the collections took place, a perimeter of at least $30 \mathrm{~m}$ between each selected plant was delimited in order to define which plants would be part of the research, and to avoid selecting plants that were very close.

Morphoagronomic descriptors. We used 41 quantitative morphoagronomic descriptors (Table 1), divided in "Plant and Leaf", "Floral" and "Fruit" described by Jesus et al. (2017). In order to evaluate all the characteristics, it was necessary to go to the field twice, once in September and again in the month of November, 2017. In the first trip to the field, we selected all the plants that had mature fruits and in the second trip, all plants that had completely open flowers. Therefore, not all the descriptors were evaluated for the same genotypes.

Methods and analyzes. For each group of descriptors, the genetic diversity among genotypes was evaluated by group formation using Ward's hierarchical grouping method (Ward, 1963), with Euclidean distance as a measure of dissimilarity. With the same group of descriptors, principal component analysis (PCA) was used to eliminate descriptors that are less important in the study of multivariate dissimilarity between genotypes, having as main criterion the maintenance of descriptors with higher eigenvector in the first components and the removal of higher eigenvector descriptors in the final components until the first two main components accounted for at least $70 \%$ of the data variation. After discarding of variables, new PCAs and hierarchical grouping were carried out with the purpose of graphically evaluating the maintenance of the groups of genotypes obtained.

In addition, the relative importance of the characters was estimated through the participation of the Mahalanobis $\left(\mathrm{D}^{2}\right)$ generalized distance components, relative to each characteristic, in the total dissimilarity observed (Singh, 1981). This methodology was used 
in order to verify similarity between variables of lesser participation of the $\mathrm{D}^{2}$ components and the variables discarded by principal components analysis. The analyzes were performed with the aid of software R (R Core Team, 2014), mainly using the packages biotools (da Silva et al, 2017), dplyr (Wickham et al, 2018) and dendextend (Galili, 2015).

\section{Results and discussion}

The set of descriptors denominated "Plant and Leaf" was evaluated in 35 individuals; for "Floral" was evaluated 16 individuals; for "Fruit" was evaluated 29 individuals.

We initially estimated the variance of the values measured between the genotypes for each of the 41 descriptors and the degree of multicollinearity in the matrix of variance and covariance between all the descriptors. Three descriptors belonging to the "Floral" group were devoid of variance (NRCF, NFPN and NSN) and, therefore, were discarded from the ACP.

Then, the remaining 38 morphoagronomic descriptors were submitted to multivariate dissimilarity analysis among the individuals. The variables were discarded until the first two components in the eigenvector matrix explained more than $70 \%$ of the total variance. In this procedure, 24 less important descriptors were eliminated (Tables 2, 3 and 4).

This high number of discard of less important descriptors may have occurred because the 41 descriptors were not applied in the 53 genotypes. Flower descriptors, for example, were applied in only 16 genotypes.

The descriptors PEL, NFN and NPN were discarded for the group "Plant and Leaf"; for the group "Floral" the descriptors ANGL, ANTL, OVL, CCED, OVD, CCID, ANTW, SEW and NBN; for the "Fruit" group the descriptors SLD, FTD, STD, BT, ST, SW, pH, PW, PPR, RLT, SS and SS/TA.

In the three groups of descriptors of "Plant and Leaf", "Floral" and "Fruit", after the discard of the variables mentioned above, the first two main components accumulate $97.8 \%, 80.5 \%$ and $82.0 \%$, respectively, of all available variation (Table 5).

The analysis of the results suggests that the remaining descriptors (LCFR, BRL, LBL, PEDL, PETL, SEL, FLD, CTD, MLW, SEW, FM, NFR, NSF, BW and $\mathrm{TA})$ are the minimum descriptors to morphoagronomic genetic diversity among passion fruit trees. And, additionally, the 26 descriptors eliminated constitute redundant morphoagronomic aspects that would not aid in the study of genetic diversity and would make data collection and analysis more laborious.

Similar results were found by Santos et al. (2011), in the study to estimate genetic parameters by multivariate analysis of two species of Passiflora and their hybrids, considered ornamental potential, based on morphological characteristics, in which, through principal component analysis, they reduced the 14 descriptors for two main components which explained $84 \%$ of the total variance. Component 1 explained $48.9 \%$ of the total variance and component 2 explained $35.12 \%$.

The correct discard of the 26 redundant descriptors and selection of the 15 minimum descriptors were validated by the hierarchical cluster analysis of Ward. When comparing the pairs of dendrograms generated by this analysis, for each group of descriptors, before and after the discard of the descriptors, the maintenance of the groups formed for two of the three groups of descriptors is verified. Only, except for the descriptors of "Plant and Leaf", where there was a subtle difference in the grouping, since genotypes 1,5 and 8 that were initially in the third group, after the discarding were reallocated in the first group (Figures 1, 2 and 3). That is, this result indicates that the discard of variables through the use of PCA was effective, since the grouping continued the same, not harming the classification of the genotypes within the groups.

Similar results were found by Campos et al. (2015), in the study to obtain the minimum efficient descriptors for mango (Mangifera indica L.), also used the Ward's method to verify the groupings before and after the discard of variables. And from the comparison between the groupings, they concluded that the use of only 34 fruit characteristics was sufficient to distinguish the genotypes evaluated in this study, optimized the 64 descriptors recommended for the characterization of this fruit tree.

The analysis of the relative contribution of the morphoagronomic descriptors, estimated by Singh's methodology (1981), used to evaluate the importance of the 41 descriptors, determined the characteristics that contributed the most to the genetic divergence between the genotypes in each group of descriptors (Tables 6, 7 and 8).

The correct discard of the 26 redundant descriptors and selection of the 15 minimum descriptors were revalidated by the relative contribution analysis of the descriptors estimated according to Singh (1981). The redundant descriptors in the PCA presented little relative contribution for all groups of descriptors.

For the set of descriptors "Plant and Leaf" the characteristics that presented the greatest relative contributions were: maximum leaf width $76.1 \%$ and leaf blade length $17.2 \%$. For the group of descriptors "Floral" the characteristics that presented the greatest relative contributions were: pedicel length $42.1 \%$, corona tip diameter $32.6 \%$ and petal length $11.8 \%$. For the group of descriptors "Fruit" the characteristic that presented the greatest relative contribution was: number of seeds per fruit $89.2 \%$.

Similar results were found by Fonseca et al. (2017), in his work to validate the morphoagronomic 
descriptors used in the protection processes of plant cultivars in Brazil, characterizing six ornamental passion fruit cultivars, in which they identified maximum leaf width (approximately 34\%) and petal length (26,17\%) as the descriptors that contributed the most to the differentiation of the analyzed cultivars. Lawinscky et al. (2014), in the work of morphological characterization and genetic diversity in Passiflora alata Curtis and $P$. cincinnata Mast, for the 16 morphological descriptors measured, the corona diameter with $43.46 \%$, the petal width with $9.81 \%$ and pedicel length with $7.49 \%$ were the main contributors to the divergence between the two species.

The results of Sousa et al. (2012) and Araújo et al. (2008), related to the relative contribution of the number of seeds per fruit were of $2.52 \%$ and $1.65 \%$ respectively. It differs from the results obtained here, since in the present work the number of seeds per fruit was the descriptor that contributed the most to the genetic divergence among the studied genotypes.
From the results obtained, we can infer that of the 41 descriptors, only 15 were relevant for the evaluation of the genetic diversity among the individuals of the population. These descriptors were: titratable acidity, bract length, leaf blade length, petal length, sepal length, pedicel length, corona filament ring length, corona tip diameter, fruit longitudinal diameter, sepal width, maximum leaf width, number of fruits, number of seeds per fruit, bark weight and fruit mass.

The genotypes sampled in Vitória da Conquista and Belo Campo represent a small genetic variability of the species. Thus, discarded descriptors for this group of genotypes may not be discarded for other groups.

However, this reduced list of morphoagronomic descriptors should represent an important working tool for research focused on the genetic and phenotypic variability of "Maracujá-do-Mato" populations, in situ or not, since the discarding of redundant variables allows saving time and material resources without loss information.

Table 1 - Quantitative morphoagronomic descriptors evaluated in passion fruit trees (Passiflora cincinnata Mast) grouped between plant parts.

\begin{tabular}{|c|c|c|c|}
\hline \multicolumn{4}{|c|}{ PLANT AND LEAF DESCRIPTORS } \\
\hline LBL & Leaf blade length & NFR & Number of fruits \\
\hline MLW & Maximum leaf width & NPN & Number of petiole nectaries \\
\hline NFN & Number of foliar nectaries & PEL & Petiole length \\
\hline \multicolumn{4}{|c|}{ FLORAL DESCRIPTORS } \\
\hline ANGL & Androgynophore length & NFPN & Number of flowers per node \\
\hline ANTL & Anther length & NRCF & $\begin{array}{l}\text { Number of colored rings on corona } \\
\text { filaments }\end{array}$ \\
\hline ANTW & Anther width & NSN & Number of sepal nectaries \\
\hline BRL & Bract length & OVD & Ovary diameter \\
\hline CCED & Corona cavity external diameter & OVL & Ovary length \\
\hline CCID & Corona cavity internal diameter & PEDL & Pedicel length \\
\hline CTD & Corona tip diameter & PETL & Petal length \\
\hline LCFR & Length of corona filament rings & SEL & Sepal length \\
\hline NBN & Number of bract nectaries & SEW & Sepal width \\
\hline \multicolumn{4}{|c|}{ FRUIT DESCRIPTORS } \\
\hline BT & Bark thickness & RLT & $\begin{array}{l}\text { Relation between longitudinal and } \\
\text { transverse fruit diameter }\end{array}$ \\
\hline BW & Bark weight & SLD & Seed longitudinal diameter \\
\hline FM & Fruit mass & SS & Soluble solids \\
\hline FLD & Fruit longitudinal diameter & SS/TA & Ratio \\
\hline FTD & Fruit transverse diameter & ST & Seed thickness \\
\hline NSF & Number of seeds per fruit & STD & Seed transverse diameter \\
\hline pH & Hydrogenionic potential & SW & Seed weight \\
\hline PPR & Pulp production & TA & Titratable acidity \\
\hline PW & Pulp weight & & \\
\hline
\end{tabular}


Table 2 - Coefficients of the six Principal Components (eigenvectors) of the "Plant and Leaf" morphoagronomic descriptors.

\begin{tabular}{ccccccc}
\hline \multirow{2}{*}{ Descriptors } & \multicolumn{7}{c}{ Coefficients } \\
\cline { 2 - 7 } & PC1 & PC2 & PC3 & PC4 & PC5 & PC6 \\
\hline LBL & 0.567 & 0.053 & -0.105 & 0.056 & 0.249 & 0.774 \\
MLW & 0.549 & 0.072 & -0.129 & 0.019 & 0.556 & -0.606 \\
NFN & -0.209 & 0.607 & -0.427 & -0.623 & 0.117 & 0.061 \\
NFR & -0.174 & 0.696 & 0.108 & 0.682 & 0.097 & 0.013 \\
NPN & 0.241 & 0.310 & 0.835 & -0.373 & -0.098 & -0.025 \\
PEL & 0.495 & 0.209 & -0.284 & 0.071 & -0.772 & -0.172 \\
\hline
\end{tabular}

LBL: leaf blade length; MLW: maximum leaf width; NFN: number of foliar nectaries; NFR: number of fruits; NPN: number of petiole nectaries; PEL: petiole length; PC: principal components.

Tabela 3 - Coefficients of the fifteen Principal Components (eigenvectors) of the "Floral" morphoagronomic descriptors.

\begin{tabular}{|c|c|c|c|c|c|c|c|c|}
\hline \multirow{2}{*}{ Descriptors } & \multicolumn{8}{|c|}{ Coefficients } \\
\hline & PC1 & PC2 & PC3 & PC4 & PC5 & PC6 & PC7 & PC8 \\
\hline ANGL & -0.030 & 0.449 & 0.189 & 0.267 & -0.217 & 0.043 & -0.014 & 0.632 \\
\hline ANTL & -0.307 & 0.057 & 0.193 & -0.079 & -0.492 & -0.252 & 0.444 & -0.183 \\
\hline ANTW & -0.105 & 0.315 & 0.332 & -0.448 & -0.003 & 0.146 & -0.401 & -0.137 \\
\hline BRL & -0.213 & -0.216 & 0.345 & -0.356 & -0.120 & -0.211 & -0.076 & 0.193 \\
\hline CCED & -0.032 & 0.000 & 0.482 & 0.336 & -0.075 & 0.319 & 0.183 & -0.506 \\
\hline CCID & -0.091 & -0.125 & 0.393 & 0.552 & 0.149 & -0.149 & -0.234 & 0.210 \\
\hline CTD & -0.427 & -0.092 & -0.055 & -0.114 & 0.010 & -0.076 & -0.044 & 0.066 \\
\hline LCFR & 0.037 & 0.449 & -0.284 & 0.068 & 0.136 & -0.235 & 0.380 & -0.028 \\
\hline NBN & 0.250 & -0.358 & -0.065 & -0.025 & -0.394 & -0.394 & -0.132 & 0.087 \\
\hline OVD & -0.287 & -0.143 & -0.345 & 0.160 & -0.069 & 0.256 & -0.375 & -0.064 \\
\hline OVL & -0.339 & -0.185 & -0.147 & 0.326 & 0.027 & -0.315 & -0.031 & -0.177 \\
\hline PEDL & 0.016 & -0.458 & 0.022 & -0.080 & -0.009 & 0.501 & 0.449 & 0.361 \\
\hline PETL & -0.421 & 0.064 & 0.012 & -0.064 & 0.191 & -0.045 & 0.128 & 0.178 \\
\hline SEL & -0.406 & -0.024 & -0.044 & -0.078 & 0.345 & 0.042 & 0.095 & 0.022 \\
\hline SEW & -0.235 & 0.164 & -0.282 & 0.103 & -0.578 & 0.331 & -0.125 & 0.000 \\
\hline \multirow{2}{*}{ Descriptors } & \multicolumn{8}{|c|}{ Coefficients } \\
\hline & PC9 & PC10 & PC11 & PC12 & PC13 & PC14 & PC15 & \\
\hline ANGL & -0.099 & 0.309 & -0.106 & 0.333 & -0.014 & -0.050 & 0.107 & \\
\hline ANTL & 0.209 & 0.086 & 0.109 & -0.022 & 0.322 & -0.326 & -0.223 & \\
\hline ANTW & 0.019 & -0.163 & 0.160 & 0.326 & 0.138 & 0.266 & -0.360 & \\
\hline BRL & -0.569 & 0.043 & -0.244 & -0.378 & 0.024 & 0.100 & 0.146 & \\
\hline CCED & -0.197 & 0.233 & 0.039 & 0.050 & -0.348 & 0.171 & 0.094 & \\
\hline CCID & 0.108 & -0.308 & 0.328 & -0.305 & 0.182 & 0.037 & -0.178 & \\
\hline CTD & -0.119 & -0.256 & 0.501 & 0.286 & -0.401 & -0.300 & 0.344 & \\
\hline LCFR & -0.466 & -0.092 & 0.324 & -0.140 & -0.040 & 0.289 & -0.239 & \\
\hline NBN & 0.133 & 0.298 & 0.294 & 0.133 & -0.261 & 0.420 & -0.122 & \\
\hline OVD & -0.309 & 0.423 & 0.118 & -0.087 & 0.068 & -0.260 & -0.412 & \\
\hline OVL & -0.169 & -0.214 & -0.424 & 0.501 & 0.171 & 0.236 & -0.037 & \\
\hline PEDL & -0.117 & -0.182 & 0.102 & 0.208 & 0.117 & 0.156 & -0.249 & \\
\hline PETL & 0.346 & 0.036 & -0.293 & -0.186 & -0.565 & 0.107 & -0.395 & \\
\hline SEL & 0.231 & 0.444 & 0.221 & -0.047 & 0.353 & 0.390 & 0.344 & \\
\hline SEW & 0.112 & -0.317 & -0.039 & -0.294 & 0.001 & 0.345 & 0.223 & \\
\hline
\end{tabular}

ANGL: androgynophore length; ANTL: anther length; ANTW: anther width; BRL: bract length; CCED: corona cavity external diameter; CCID: corona cavity internal diameter; CTD: corona tip diameter; LCFR: length of corona filament rings; NBN: number of bract nectaries; NFPN: number of flowers per node; NRCF: number of colored rings on corona filaments; NSN: number of sepal nectaries; OVD: ovary diameter; OVL: ovary length; PEDL: pedicel length; PETL: petal length; SEL: sepal length; SEW: sepal width; PC: principal components. 
Tabela 4 - Coefficients of the seventeen Principal Components (eigenvectors) of the "Fruit" morphoagronomic descriptors.

\begin{tabular}{|c|c|c|c|c|c|c|c|c|c|}
\hline \multirow{2}{*}{ Descriptors } & \multicolumn{9}{|c|}{ Coefficients } \\
\hline & PC1 & PC2 & PC3 & PC4 & PC5 & PC6 & PC7 & PC8 & PC9 \\
\hline BT & 0.169 & -0.367 & -0.387 & -0.085 & 0.029 & 0.084 & -0.072 & -0.054 & 0.120 \\
\hline BW & 0.347 & -0.094 & -0.138 & -0.095 & -0.154 & 0.263 & -0.123 & 0.084 & -0.357 \\
\hline FLD & 0.351 & -0.017 & -0.033 & -0.271 & 0.121 & -0.143 & -0.281 & 0.068 & 0.129 \\
\hline FM & 0.375 & 0.106 & -0.023 & 0.046 & -0.107 & 0.102 & -0.135 & 0.088 & -0.310 \\
\hline FTD & 0.333 & 0.137 & -0.104 & 0.089 & -0.304 & 0.174 & -0.175 & -0.196 & 0.113 \\
\hline NSF & 0.234 & 0.331 & -0.094 & -0.262 & -0.183 & -0.162 & 0.406 & -0.175 & 0.361 \\
\hline pH & -0.224 & -0.022 & 0.288 & -0.299 & -0.272 & -0.312 & -0.100 & -0.308 & -0.313 \\
\hline PPR & -0.027 & 0.427 & 0.273 & 0.324 & 0.216 & -0.153 & -0.249 & 0.190 & 0.112 \\
\hline PW & 0.286 & 0.325 & 0.152 & 0.228 & -0.009 & -0.075 & -0.203 & 0.089 & -0.203 \\
\hline RLT & 0.179 & -0.137 & 0.047 & -0.443 & 0.428 & -0.361 & -0.232 & 0.268 & 0.112 \\
\hline SLD & 0.220 & -0.293 & 0.161 & 0.171 & 0.132 & -0.391 & 0.125 & -0.393 & -0.394 \\
\hline SS & -0.153 & 0.116 & -0.552 & 0.163 & 0.104 & -0.224 & -0.032 & 0.103 & -0.173 \\
\hline SS/TA & -0.141 & -0.040 & -0.400 & 0.207 & -0.333 & -0.485 & -0.091 & 0.251 & -0.063 \\
\hline ST & 0.206 & -0.287 & 0.168 & 0.263 & 0.169 & 0.038 & 0.526 & 0.407 & -0.083 \\
\hline STD & 0.146 & -0.352 & 0.087 & 0.464 & -0.027 & -0.135 & -0.262 & -0.300 & 0.465 \\
\hline SW & 0.321 & 0.209 & -0.054 & 0.026 & -0.068 & -0.326 & 0.383 & -0.051 & 0.068 \\
\hline TA & -0.014 & 0.241 & -0.312 & 0.074 & 0.588 & 0.123 & 0.059 & -0.460 & -0.145 \\
\hline \multirow{2}{*}{ Descriptors } & \multicolumn{9}{|c|}{ Coefficients } \\
\hline & PC10 & PC11 & PC12 & PC13 & PC14 & PC15 & PC16 & PC17 & \\
\hline FLD & -0.076 & -0.190 & -0.044 & 0.059 & 0.012 & -0.156 & -0.771 & -0.002 & \\
\hline SLD & -0.368 & 0.156 & 0.289 & 0.265 & -0.007 & -0.045 & -0.002 & 0.000 & \\
\hline FTD & -0.071 & -0.251 & 0.015 & 0.184 & 0.237 & -0.622 & 0.319 & 0.000 & \\
\hline STD & 0.161 & -0.036 & -0.367 & 0.004 & -0.131 & 0.239 & 0.039 & 0.000 & \\
\hline BT & 0.460 & 0.340 & 0.533 & -0.164 & 0.088 & -0.059 & 0.004 & 0.000 & \\
\hline ST & 0.349 & -0.287 & -0.091 & 0.176 & 0.169 & -0.148 & -0.063 & 0.000 & \\
\hline FM & 0.088 & 0.039 & -0.082 & -0.046 & -0.079 & 0.227 & 0.060 & -0.789 & \\
\hline NSF & 0.118 & 0.021 & 0.092 & 0.454 & 0.046 & 0.375 & 0.031 & 0.000 & \\
\hline BW & 0.060 & -0.136 & -0.069 & 0.134 & -0.501 & 0.217 & 0.108 & 0.496 & \\
\hline SW & -0.010 & 0.133 & -0.144 & -0.609 & -0.325 & -0.253 & 0.027 & 0.070 & \\
\hline pH & 0.592 & -0.134 & -0.134 & 0.003 & 0.008 & -0.129 & -0.028 & 0.000 & \\
\hline PW & 0.112 & 0.250 & -0.058 & -0.169 & 0.587 & 0.250 & -0.029 & 0.356 & \\
\hline PPR & 0.243 & 0.008 & 0.420 & 0.193 & -0.404 & -0.141 & 0.029 & 0.000 & \\
\hline RLT & -0.034 & -0.051 & -0.132 & 0.018 & 0.070 & 0.006 & 0.523 & 0.001 & \\
\hline SS & 0.121 & 0.378 & -0.419 & 0.373 & -0.049 & -0.226 & -0.064 & 0.000 & \\
\hline SS/TA & -0.093 & -0.478 & 0.238 & -0.117 & 0.085 & 0.196 & 0.029 & 0.000 & \\
\hline TA & 0.150 & -0.430 & 0.001 & -0.138 & 0.060 & 0.106 & 0.019 & 0.000 & \\
\hline
\end{tabular}

BT: bark thickness; BW: bark weight; FM: fruit mass; FLD: fruit longitudinal diameter; FTD: fruit transverse diameter; NSF: number of seeds per fruit; $\mathrm{pH}$ : hydrogenionic potential; PPR: pulp production; PW: pulp weight; RLT: relation between longitudinal and transverse fruit diameter; SLD: seed longitudinal diameter; SS: soluble solids; SS/TA: ratio; ST: seed thickness; STD: seed transverse diameter; SW: seed weight; TA: titratable acidity; PC: principal components. 
Table 5 - Estimates of the variances (eigenvalue) and accumulated variance (\%) of the minimum morphoagronomic descriptors of the "Plant and Leaf", "Floral" and "Fruit" groups obtained for passion fruit of the bush (Passiflora cincinnata Mast).

\begin{tabular}{|c|c|c|c|c|c|c|}
\hline \multicolumn{7}{|c|}{ Plant and Leaf } \\
\hline \multirow[b]{2}{*}{ Components } & \multicolumn{3}{|c|}{ Before Discard } & \multicolumn{3}{|c|}{ After the Discard } \\
\hline & $\begin{array}{l}\text { Standard } \\
\text { Deviation }\end{array}$ & Variance & $\begin{array}{l}\text { Accumulated } \\
\text { Proportion }\end{array}$ & $\begin{array}{l}\text { Standard } \\
\text { Deviation }\end{array}$ & Variance & $\begin{array}{c}\text { Accumulated } \\
\text { Proportion }\end{array}$ \\
\hline PC1 & 1.705 & 0.484 & 0.484 & 1.422 & 0.674 & 0.674 \\
\hline PC2 & 1.120 & 0.209 & 0.693 & 0.955 & 0.304 & 0.978 \\
\hline PC3 & 0.944 & 0.149 & 0.842 & 0.256 & 0.022 & 1.000 \\
\hline \multicolumn{7}{|c|}{ Floral } \\
\hline & \multicolumn{3}{|c|}{ Before Discard } & \multicolumn{3}{|c|}{ After the Discard } \\
\hline Components & $\begin{array}{l}\text { Standard } \\
\text { Deviation }\end{array}$ & Variance & $\begin{array}{c}\text { Accumulated } \\
\text { Proportion }\end{array}$ & $\begin{array}{l}\text { Standard } \\
\text { Deviation }\end{array}$ & Variance & $\begin{array}{c}\text { Accumulated } \\
\text { Proportion }\end{array}$ \\
\hline PC1 & 2.213 & 0.327 & 0.327 & 1.751 & 0.511 & 0.511 \\
\hline PC2 & 1.659 & 0.184 & 0.510 & 1.327 & 0.294 & 0.805 \\
\hline PC3 & 1.589 & 0.168 & 0.679 & 0.795 & 0.105 & 0.910 \\
\hline \multicolumn{7}{|c|}{ Fruit } \\
\hline & \multicolumn{3}{|c|}{ Before Discard } & \multicolumn{3}{|c|}{ After the Discard } \\
\hline Components & $\begin{array}{l}\text { Standard } \\
\text { Deviation }\end{array}$ & Variance & $\begin{array}{l}\text { Accumulated } \\
\text { Proportion }\end{array}$ & $\begin{array}{l}\text { Standard } \\
\text { Deviation }\end{array}$ & Variance & $\begin{array}{c}\text { Accumulated } \\
\text { Proportion }\end{array}$ \\
\hline PC1 & 2.527 & 0.376 & 0.376 & 1.745 & 0.609 & 0.609 \\
\hline PC2 & 1.654 & 0.161 & 0.536 & 1.027 & 0.211 & 0.820 \\
\hline PC3 & 1.460 & 0.125 & 0.662 & 0.764 & 0.117 & 0.936 \\
\hline
\end{tabular}

PC: principal components.

Table 6 - Relative contribution of the descriptors "Plant and Leaf", evaluated in passion fruit trees (Passiflora cincinnata Mast), by the method proposed by Singh (1981).

\begin{tabular}{cccc}
\hline \multirow{2}{*}{ Descriptors } & \multicolumn{3}{c}{ Plant and Leaf } \\
\cline { 2 - 4 } & S.j & Proportion & $\begin{array}{c}\text { Accumulated } \\
\text { Proportion }\end{array}$ \\
\hline MLW & 189942900.000 & 0.761 & $76.1 \%$ \\
LBL & 42857320.000 & 0.172 & $93.3 \%$ \\
PEL & 16051370.000 & 0.064 & $99.7 \%$ \\
NFR & 513406.900 & 0.002 & $99.9 \%$ \\
NFN & 172507.200 & 0.001 & $100 \%$ \\
NPN & 3420.479 & 0.000 & $100 \%$ \\
\hline
\end{tabular}

LBL: leaf blade length; MLW: maximum leaf width; NFN: number of foliar nectaries; NFR: number of fruits; NPN: number of petiole nectaries; PEL: petiole length; S.j: Singh's analysis. 
Table 7 - Relative contribution of the descriptors "Floral", evaluated in passion fruit trees (Passiflora cincinnata Mast), by the method proposed by Singh (1981).

\begin{tabular}{cccc}
\hline \multirow{2}{*}{ Descriptors } & \multicolumn{3}{c}{ Floral } \\
\cline { 2 - 4 } & S.j & Proportion & $\begin{array}{c}\text { Accumulated } \\
\text { Proportion }\end{array}$ \\
\hline PEDL & 1039896.000 & 0.422 & $42.2 \%$ \\
CTD & 801724.400 & 0.326 & $74.8 \%$ \\
PETL & 290660.500 & 0.118 & $86.6 \%$ \\
SEL & 149597.600 & 0.061 & $92.7 \%$ \\
LCFR & 73179.780 & 0.030 & $95.6 \%$ \\
BRL & 57749.280 & 0.023 & $98.0 \%$ \\
& & & \\
ANTL & 14667.280 & 0.006 & $98.6 \%$ \\
SEW & 11995.110 & 0.005 & $99.1 \%$ \\
ANGL & 8605.322 & 0.003 & $99.4 \%$ \\
OVL & 6488.218 & 0.003 & $99.7 \%$ \\
OVD & 2819.501 & 0.001 & $99.8 \%$ \\
ANTW & 2714.684 & 0.001 & $99.9 \%$ \\
CCED & 1161.347 & 0.000 & $100 \%$ \\
NBN & 800.209 & 0.000 & $100 \%$ \\
CCID & 365.866 & 0.000 & $100 \%$ \\
\hline
\end{tabular}

ANGL: androgynophore length; ANTL: anther length; ANTW: anther width; BRL: bract length; CCED: corona cavity external diameter; CCID: corona cavity internal diameter; CTD: corona tip diameter; LCFR: length of corona filament rings; NBN: number of bract nectaries; NFPN: number of flowers per node; NRCF: number of colored rings on corona filaments; NSN: number of sepal nectaries; OVD: ovary diameter; OVL: ovary length; PEDL: pedicel length; PETL: petal length; SEL: sepal length; SEW: sepal width; S.j: Singh's analysis.

Table 8 - Relative contribution of the descriptors “Fruit", evaluated in passion fruit trees (Passiflora cincinnata Mast), by the method proposed by Singh (1981).

\begin{tabular}{cccc}
\hline \multirow{2}{*}{ Descriptors } & \multicolumn{3}{c}{ Fruit } \\
\cline { 2 - 4 } & S.j & Proportion & $\begin{array}{c}\text { Accumulated } \\
\text { Proportion }\end{array}$ \\
\hline NSF & 1779174000.000 & 0.892 & $89.2 \%$ \\
FM & 129498500.000 & 0.065 & $95.7 \%$ \\
BW & 33522820.000 & 0.017 & $97.4 \%$ \\
PW & 20647430.000 & 0.010 & $98.5 \%$ \\
FLD & 15375360.000 & 0.008 & $99.2 \%$ \\
FTD & 7748771.000 & 0.004 & $99.6 \%$ \\
TA & 6088972.000 & 0.003 & $99.9 \%$ \\
SW & 1484393.000 & 0.001 & $100 \%$ \\
SS & 153372.900 & 0.000 & $100 \%$ \\
BT & 22186.300 & 0.000 & $100 \%$ \\
SLD & 4256.817 & 0.000 & $100 \%$ \\
STD & 3515.067 & 0.000 & $100 \%$ \\
pH & 1132.761 & 0.000 & $100 \%$ \\
ST & 1054.558 & 0.000 & $100 \%$ \\
RLT & 472.513 & 0.000 & $100 \%$ \\
PPR & 157.854 & 0.000 & $100 \%$ \\
SS/TA & 33.164 & 0.000 & $100 \%$ \\
\hline
\end{tabular}

BT: bark thickness; BW: bark weight; FM: fruit mass; FLD: fruit longitudinal diameter; FTD: fruit transverse diameter; NSF: number of seeds per fruit; $\mathrm{pH}$ : hydrogenionic potential; PPR: pulp production; PW: pulp weight; RLT: relation between longitudinal and transverse fruit diameter; SLD: seed longitudinal diameter; SS: soluble solids; SS/TA: ratio; ST: seed thickness; STD: seed transverse diameter; SW: seed weight; TA: titratable acidity; S.j: Singh's analysis. 


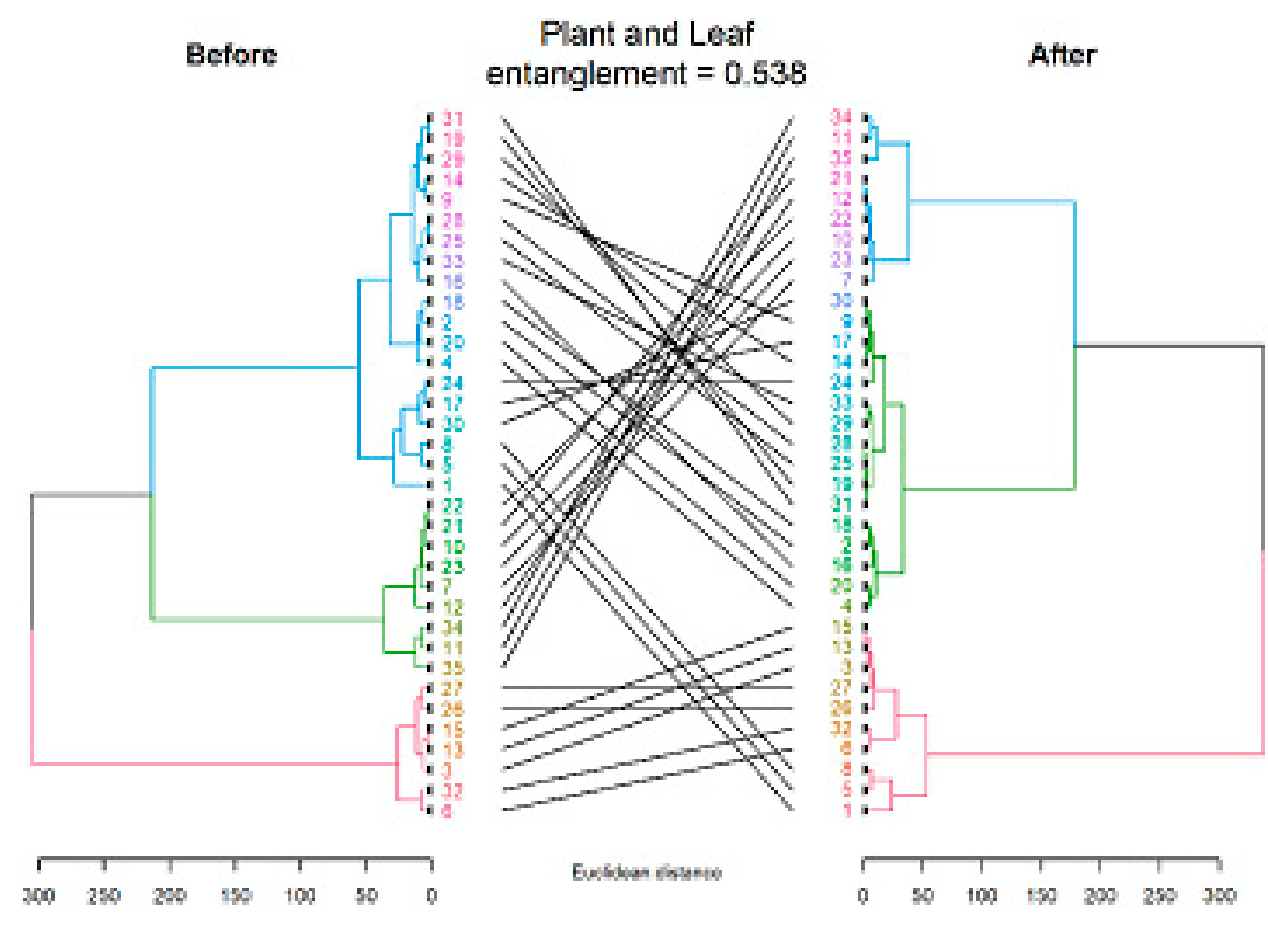

Figure 1 - Dendrogram of the dissimilarity pattern obtained by Ward's method, based on Euclidian distance for Passiflora cincinnata, Mast using descriptors for "Plant and Leaf" before and after of variables.

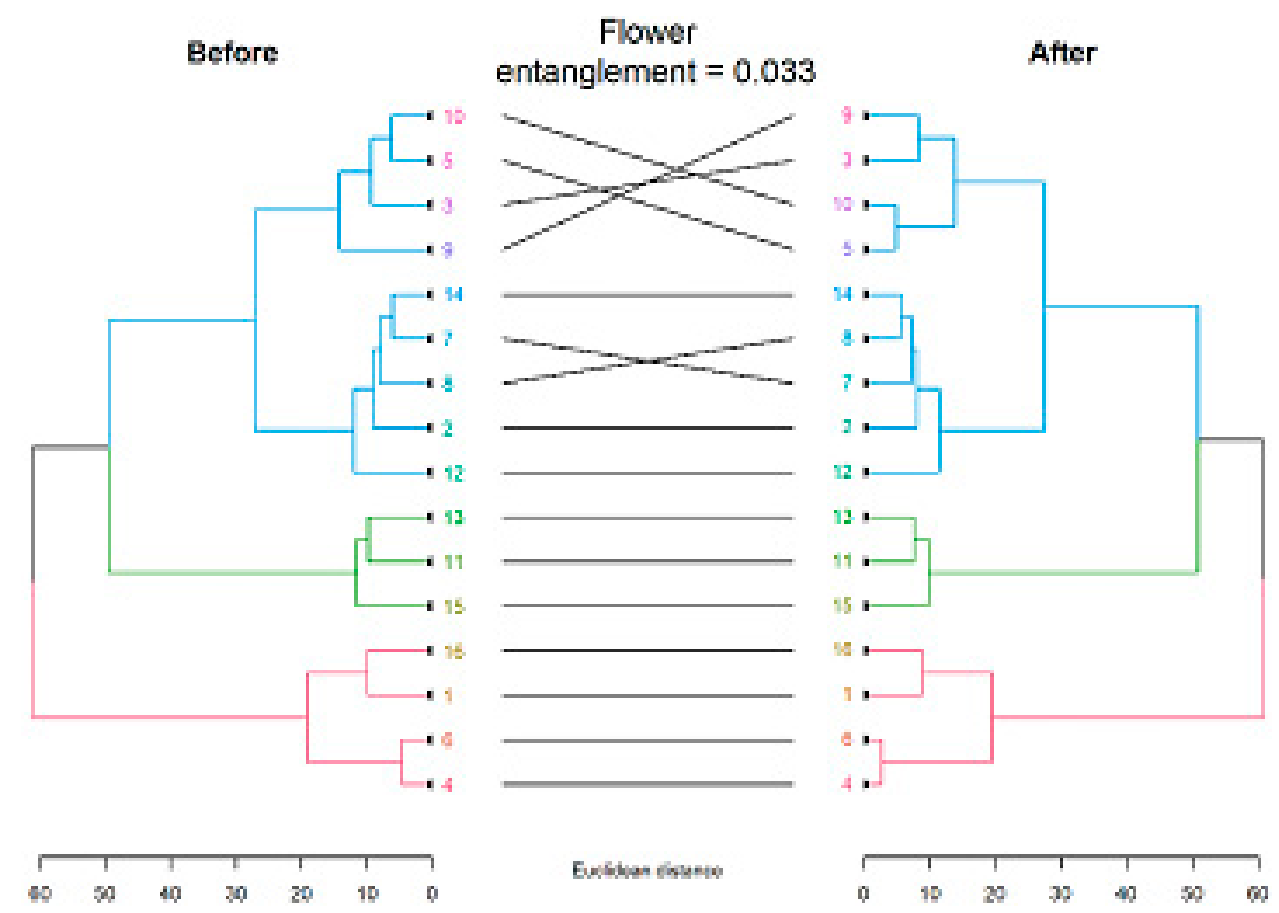

Figure 2 - Dendrogram of the dissimilarity pattern obtained by Ward's method, based on Euclidian distance for Passiflora cincinnata, Mast using descriptors for "Floral" before and after of variables. 


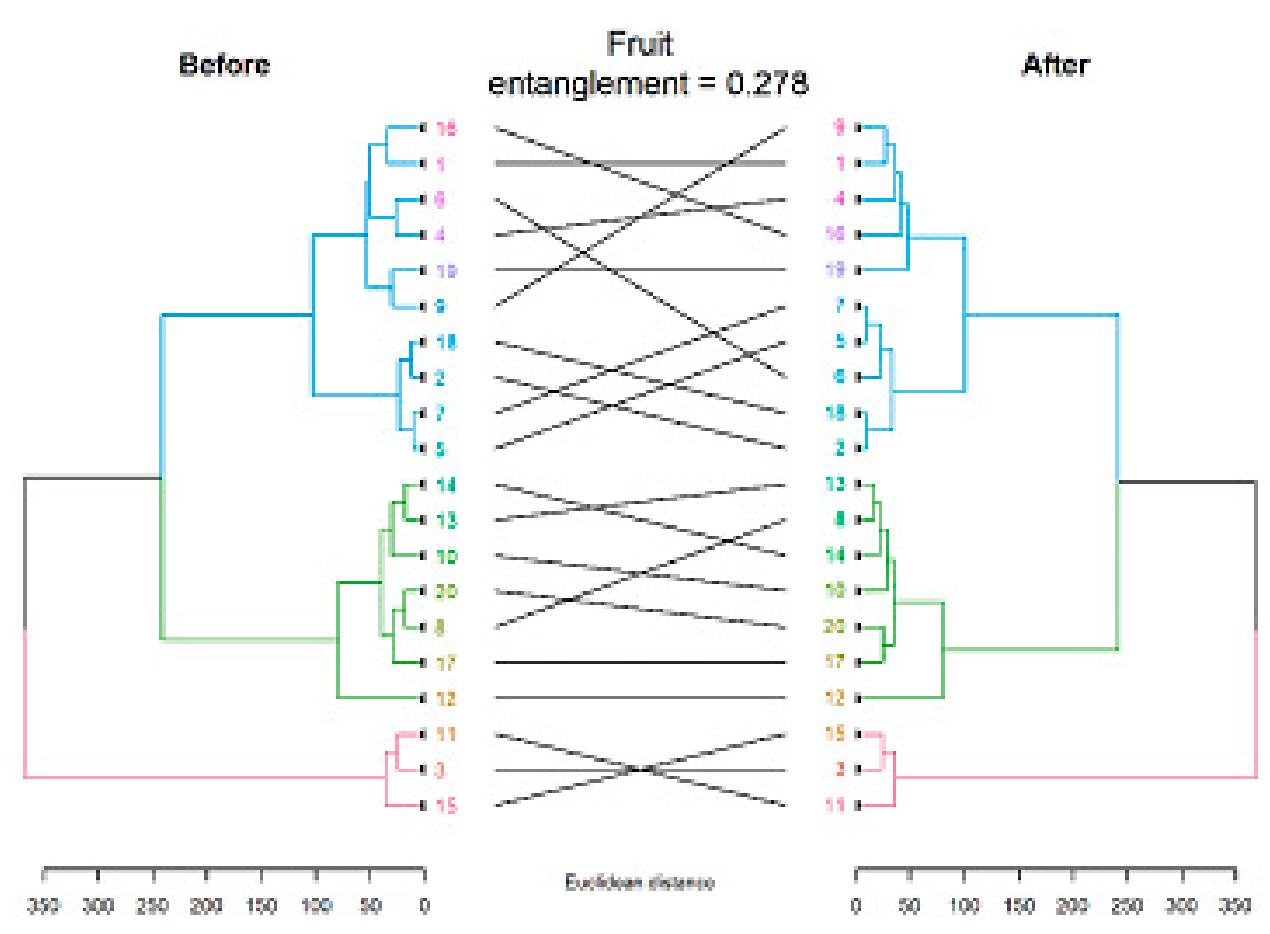

Figure 3 - Dendrogram of the dissimilarity pattern obtained by Ward's method, based on Euclidian distance for Passiflora cincinnata, Mast using descriptors for "Fruit" before and after of variables.

\section{Conclusions}

Based on the results obtained, it was possible to identify and discard redundant variables of morphoagronomic descriptors through the analysis of main components and validated by Ward's (1963) and Singh's (1981) methods, without prejudice to diversity estimation and genotyping, to propose a reduced list of morphoagronomic descriptors. These descriptors were: titratable acidity, bract length, leaf blade length, petal length, sepal length, pedicel length, corona filament ring length, corona tip diameter, fruit longitudinal diameter, sepal width, maximum leaf width, number of fruits, number of seeds per fruit, bark weight and fruit mass. The genotypes sampled in Vitória da Conquista and Belo Campo represent a small genetic variability of the species. Thus, discarded descriptors for this group of genotypes may not be discarded for other groups.

\section{Acknowledgements}

We thank Coordenação de Aperfeiçoamento de Pessoal de Nível Superior (CAPES) and Programa de Pós Graduação em Genética, Biodiversidade e Conservação of UESB for the grant awarded and Research Support .

\section{REFERENCES}

ARAÚJO, FPD.; SILVA, ND. \& QUEIROZ, MAD. Divergência genética entre genótipos de Passiflora cincinnata Mast com base em descritores morfoagronômicos. Revista Brasileira de Fruticultura, vol. 30, no. 3, p. 723-730, 2008.

BARBOSA, L.; LOPES, PS.; REGAZZI, AJ.; GUIMARÃES, SEF. \& TORRES, RA. Seleção de variáveis de desempenho de suínos por meio da análise de componentes principais. Arquivo Brasileiro de Medicina Veterinária e Zootecnia, vol. 57, no. 6, p. 805-810, 2005.

BEALE, EML.; KENDALL, MG. \& MANN, DW. The discarding of variables in multivariate analysis. Biometrika, vol. 54, no. 3, p. 357-366, 1967.

CAMPOS, AL.; PREISIGKE, SC.; NEVES, LG.; LUZ, PB.; BARELLI, MAA. \& KRAUSE, W. Obtenção dos descritores mínimos eficientes para mangueira pelo método de Ward. Magistra, vol. 27, no. 2, p. 266-273, 2015.

CLIMATE-DATA.ORG. Clima: Vitória da Conquista: Climograma, Temperatura e Tabela climática Vitória da Conquista - Climate-Data.org. Disponível em: $<$ https:// pt.climate-data.org/location/293/>. Acesso em: 12 mar. 2018. 
CUNHA, MAP.; BARBOSA, LV. \& JUNQUEIRA, NT Espécies de maracujazeiro. In: LIMA, AA. Maracujá produção: aspectos técnicos. Brasilia, DF: Embrapa-SCT, 2002. p. 15-22.

DA SILVA, A.R.; MALAFAIA, G.; MENEZES, I.P.P. Biotools: an R function to predict spatial gene diversity via an individual-based approach. Genetics and Molecular Research, 16: gmr16029655, 2017.

FALEIRO, FG.; PEIXOTO, JR.; VIANA, AP.; BRUCKNER, CH.; LARANJEIRA, FF.; DAMASCENO, F.; MELETTI, LMM.; CONSOLI, L.; SOUSA, MAF.; SILVA, MS.; PEREIRA, MG.; STENZEL, N \& SHARMA, RD. Demandas para as Pesquisas Relacionadas ao Melhoramento Genético. In: FALEIRO, FG.; JUNQUEIRA, NTV. \&BRAGA, MF. Maracujá: demandas para a pesquisa. Planaltina: Embrapa Cerrados, 2006a. p. 27-34.

FONSECA, KG.; FALEIRO, FG.; JUNQUEIRA, NTV.; BARTH, M. \& FELDBERG, NP. Morphoagronomic and molecular characterization of ornamental passion fruit cultivars. Pesquisa Agropecuária Brasileira, vol.52, no.10, p.849-860, 2017.

GALILI, T. 2015. Dendextend: an R package for visualizing, adjusting, and comparing trees of hierarchical clustering. Bioinformatics. DOI: 10.1093/bioinformatics/ btv42, 2015.

JESUS, ON.; OLIVEIRA, EJ.; FALEIRO, FG.; SOARES. TL. \& GIRARDI, EA. Illustrated morpho-agronomic descriptors for Passiflora spp. Brasília: Embrapa, 2017, $126 \mathrm{p}$.

JUNIOR, MXO.; JOSÉ, ARS.; REBOUÇAS, TNH,; MORAIS, OM. \& DOURADO, FWN. Superação de dormência de maracujá-do-mato (Passiflora cincinnata MAST.). Revista Brasileira de Fruticultura, vol. 32, no. 2, p. 584-590, 2010.

JUNQUEIRA, NTV.; BRAGA, MF.; FALEIRO, FG.; PEIXOTO, JR. \& BERNACCI, LC. Potencial de espécies silvestres de maracujazeiro como fonte de resistência a doenças. In: FALEIRO, FG.; JUNQUEIRA, NTV. \& BRAGA, MF. Maracujá: germoplasma e melhoramento genético. Planaltina: Embrapa Cerrados, 2005. p. 79-108.

KIILL, LHP.; ALVAREZ, IA.; RESENDE, GM.; YANOMELO, AM.; ARAÚJO, FP. \& OLIVEIRA, AR. Flora, fauna e microrganismos. In: ALBUQUERQUE, ACS. \& SILVA, AG. Agricultura tropical: quatro décadas de inovações tecnológicas, institucionais e políticas. Brasília: Embrapa Informação Tecnológica, 2008. p. 431-452.
LAWINSCKY, PR.; SOUZA, MM.; BELO, GO.; VIANA, AJC.; MELO, CAF. \& OLIVEIRA, CSL. Morphological characterization and genetic diversity in Passiflora alata Curtis and P. cincinnata Mast. (Passifloraceae). Brazilian Journal of Botany, vol. 37, no. 3, p. 261-272, 2014.

LOPES, JF. \& CARVALHO, SIC. A Variabilidade Genética e o Pré-melhoramento. In: FALEIRO, FG.; NETO, ALF. \& JUNIOR, WQR. Pré-melhoramento, melhoramento e pós-melhoramento: estratégias e desafios. Planaltina: Embrapa Cerrados, 2008. p. 65-74.

MACHADO, VLS.; GRILLI, GVG.; FERREIRA, FR.; JUNQUEIRA, NTV.; FALEIRO, FG.; BERNACCI, LC.; CERVI, AC. \& RUGGIERO, C. Estado Atual e Perspectivas para a Obtenção dos Descritores do Maracujazeiro. In: FALEIRO, FG.; JUNQUEIRA, NTV. \& BRAGA, MF. Maracujá: demandas para a pesquisa. Planaltina: Embrapa Cerrados, 2006. p. 51-54.

NUNES, TS. \& QUEIROZ, LP. Flora da Bahia: Passifloraceae. Sitientibus Série Ciências Biológicas, vol. 6, no. 3, p. 194-226, 2006.

OLIVEIRA, JC. \& RUGGiERO, C. Espécies de maracujá com potencial agronômico. In: FALEIRO, FG.; JUNQUEIRA, NTV. \& BRAGA, MF. Maracujá: germoplasma e melhoramento genético. Planaltina: Embrapa Cerrados, 2005. p. 142-158.

PEREIRA, JS.; TELES, VO.; SILVA, JMF. \& PARENTE, JD. Avaliação do crescimento do caule do maracujá-domato (Passiflora cincinnata Mast.) através de três formas de manejo. In: IV Encontro Universitário da UFC no Cariri, Juazeiro do Norte, Brasil, 2012. p. 1-5.

R CORE TEAM. R: A language and environment for statistical computing. R Foundation for Statistical Computing, Viena, Austria. 2014.

SANTOS, EA.; SOUZA, MM.; VIANA, AP.; ALMEIDA, AAF.; FREITAS, JCO. \& LAWINSCKY, PR. Multivariate analysis of morphological characteristics of two species of passion flower with ornamental potential and of hybrids between them. Genetics and Molecular Research, vol. 10, no. 4, p. 2457-2471, 2011.

SINGH, D. The relative importance of characters affecting genetic divergence. The Indian Journal of Genetics e Plant Breeding, vol. 41, no. 1, p. 237-245, 1981. 
SOUSA, LD.; SILVA, EM.; GOMES, RLF.; LOPES, ACA. \& SILVA, ICV. Caracterização e divergência genética de genótipos de Passiflora edulis e P. cincinnata com base em características físicas e químicas de frutos. Revista Brasileira de Fruticultura, vol. 34, no. 3, p. 832-839, 2012.

WARD, JHJ. Hierarchical Grouping to Optimize an Objective Function. Journal of the American Statistical Association, vol. 58, no. 1, p. 236-244, 1963.
WICKHAM, H.; FRANÇOIS, R.; HENRY, L. \& MÜLLER, K. Dplyr: A Grammar of Data Manipulation. R package version 0.7.6. 2018. https://CRAN.R-project. org/package $=$ dplyr. 